\title{
The Evolution Of The American Brewing Industry
}

\author{
Alfred G. Warner, Penn State Erie, USA
}

\begin{abstract}
This case provides industry and historical background to firm specific cases in the brewing industry. It also stands alone as an industry evolution case. This case is intended for MBA or upper level undergraduate classes in strategic management.
\end{abstract}

Keywords: brewing history, Anheuser-Busch, Miller, microbrewing

\section{INTRODUCTION}

eer, if drank with moderation, softens the temper, cheers the spirit and promotes health." (Thomas
Jefferson)

"Let no man thirst for good beer." (Sam Adams)

Beer has been brewed in the U.S. since the Pilgrims arrived - and it is held that they landed at Plymouth rather than further south because beer was running short on the Mayflower. According to the diary of one passenger: "We could not now take time for further search...our victuals being much spent, especially our beer..." (Beer Institute, 2010). Whether this is the case or, as others have it, the landing was motivated by sailors afraid of running out of beer on the homeward voyage, beer mattered. Production in the new colonies was in the form of ales and porters which had traveled with British settlers. Small breweries were operating in major cities well before the Revolutionary War. George Washington, for example, had a strong preference for porter, particularly from Philadelphia brewer Robert Hare (Baron, 1962) and as the epigrams indicate, other founding fathers had an equivalent appreciation. Still, beer was not by any means the most popular alcoholic beverage in the new country: whiskey, cider, and rum all outpaced demand for beer, particularly since brewing ales was an iffy proposition with respect to quality and the product was often sour. Preferences began to change in the 1840's as a result of new beer styles accompanying German immigration.

Despite the colonial beginnings, the story of beer and brewing in the United States is mostly a German one. Immigration from Germany over the period 1840-80 constituted one of the two massive movements of people from Northern Europe to the United States. The Irish, in the other movement, were driven by the Great Potato Famine, but German immigration was driven mostly by political unrest and the failed revolution of 1848 , though economic distress also played a role. Germany, at that time, was a loose confederation of states comprising the Federation, though it was dominated by the Prussians and Austrians militarily and politically. Both were reactionary and resistant to new political ideas spreading from America, France, and England, such as liberty or political freedom. A bitter struggle for control emerged between merchants, tradespeople, and industry on one side and the landowners and military powers on the other. Official repression initiated the emigration to the United States in the early 1840's.

This reached a head when the French Revolution of 1848 triggered a similar rebellion by liberals in Germany ("liberal" here used in the classical sense, meaning those who espouse limited government and extensive individual political and commercial freedoms). Ultimately, this revolution was suppressed and in the aftermath, which lasted for decades, many of the participants and sympathizers were forced to flee. Many were young, educated or skilled, and reasonably well-to-do (Steiner, 2000). Thus, they were able to go beyond settling at a port of entry (as the Irish immigrants generally did) and push on to the Midwest. The largest centers of German immigration, at this time, included New York City and Baltimore, but also Milwaukee, St. Louis, and Cincinnati 
(the so-called "German Triangle"). By 1860, over 1.3 million German immigrants had entered the U.S., a number which grew to nearly three million by 1890 ("Germans in America", 2009).

The motivation for clustering together in these cities was to preserve some stability and security in an uncertain new world through continuation of older traditions and habits. In most areas where Germans settled, German bakers, butchers and dry grocers quickly set up shop and social groups, such as the Maennerchor (a singing society) or the Turners (derived from Turnverein; an athletic club), and German language newspapers (St. Louis had seven, at one time) sustained cultural identity. And, of course, a large contributor to both culinary habits and social ventures was the German brewing tradition.

German beers were Bavarian lager-styled; i.e., compared to the ales being brewed in the U.S., they were light, effervescent, lower in alcohol, and because of the fermentation conditions, more reliable in quality. They quickly caught on, not only with the immigrants, but also the larger American population. Breweries sprang up in most northern cities and towns in great numbers. The proliferation had several causes. Brewing was still very labor intensive; therefore, the scale of production was quite small. Also, transportation was not well developed, aside from water routes. Because beer couldn't be shipped long distances without spoiling, this meant that brewers had to be local. Most sold their output within just a few miles of the brewery. Even so, in cities such as Philadelphia and New York, the demand was so high that dozens of brewers could survive. By 1860, Brooklyn alone in New York City had 50 breweries and Philadelphia had near a hundred.

Many brewers, whose firms would later dominate the American market, got their start in Milwaukee during the pre-Civil War period. Jacob Best's brewery, which would later be called Pabst Brewing when his son-in-law, Frederick Pabst, took over the firm), began producing beer in 1844. Joseph Schlitz purchased a share in a brewery begun by August Krug in 1849, and by 1858, the firm was in his name. Miller Brewing began production in 1855 (Ogle, 2006).

\section{A REVOLUTION IN BREWING: 1865-1900}

"I am a firm believer in the people. If given the truth, they can be depended upon to meet any national crisis. The great point is to bring them the real facts, and beer." (Abraham Lincoln)

"Oh, lager beer! It makes good cheer and proves the poor man's worth; It cools the body through and through, and regulates the health." (Anonymous)

By the end of the Civil War, the U.S. had thousands of breweries operating. Most were very small: even the largest brewers operated plants in the 12,000 barrel (bbl)/year range. Within 30 years, the number of brewers would drop precipitously (see Figure 1), but large producers would be pushing the one million bbl/year scale and overall output increased by about $900 \%$. What happened to the brewing industry was similar to what was occurring in American industry generally. This period of technological revolution, largely driven by the introduction of the steam engine, led to massive changes not only in transportation but also in production (Stack, 2000).

One cause of this shift was the emergence of Midwestern "shipping" brewers. Brewers in Milwaukee, Cincinnati, and St. Louis found that local demand was too small to absorb all the output of their plants so they began to seek new markets for their beer. Best Brewing, for example (as discussed above) was a Milwaukee brewer that had already been supplying the Chicago market. This worked for two reasons: first, access via Lake Michigan was inexpensive and effective. Second, Chicago was growing at a pace that outstripped the ability of home-town brewers to keep pace. Later, in 1871, fire would destroy much of the city's brewing capacity and Best Brewing expanded to fill the shortfall. Still, limitations in transportation technology made this a costly and uncommon approach. Brewers wanting to ship had to overcome not just the intrinsic costs of production but also the added cost of transportation relative to the product of local brewers. Longer distances meant higher costs, hence a less competitive position. In addition, transportation was relatively slow and beer has a limited shelf life. Lacking time and temperature controls, long distance shipping was not feasible. 


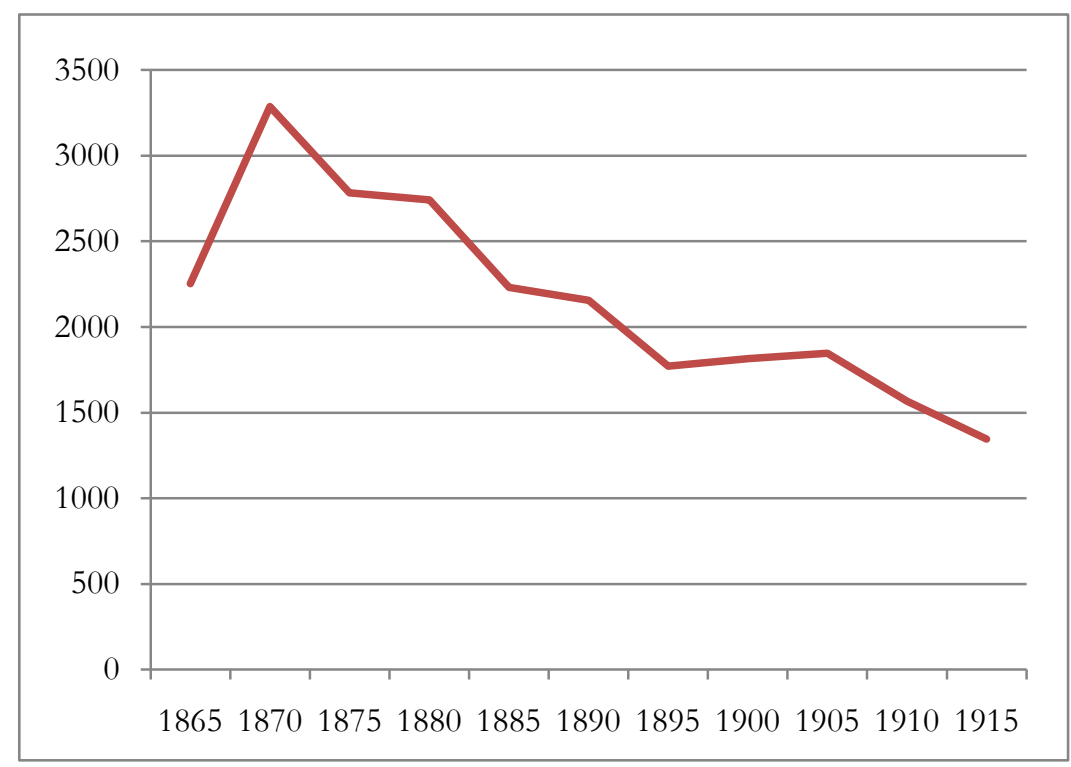

Figure 1: Brewery Population 1965-1915

(Source: Stack, 2000)

The growth of the American rail network was one key to the shift. Between 1865 and 1893, over 150,000 miles of new track were laid, connecting major cities with ever larger numbers of smaller towns. The costs of transportation dropped significantly and the radius that could be profitably served by shipping brewers expanded greatly. Even so, in order to take advantage of this, several issues regarding how beer was shipped and marketed had to be resolved. Perhaps the most innovative brewer in this regard was Adolphus Busch.

Busch had married the daughter of Eberhard Anheuser, a very successful St. Louis soap maker who also owned (as part of a debt settlement) the Bavarian Brewery. Anheuser didn't know much about brewing and when the operation came close to failing in 1865, Busch stepped in to purchase a share and to take over operations. Busch was not a brew master but had worked in family breweries in Germany and after moving to St, Louis, had gone into business operating a brewing supply firm so he understood the processes and the inputs well. He soon decided that if he was to save the brewery, he would also have to expand beyond the city. Since the northern brewers had already penetrated the upper Midwest, he chose to target the southwest, including Texas.

Most brewers shipped beer in wooden kegs. As long as the brewer could control distribution through a company saloon, this presented no problems. However, it wasn't unknown for tavern owners to swap out the good beer in a keg with lower quality product while retaining a higher price. Busch recognized this would damage both sales and the firm's reputation, so he chose to fight potential fraud by shipping bottled beer - which required him to develop the first large scale automated bottling line. By 1872, his brewery was processing about 40,000 bottles per day. Subsequent advances such as an automatic bottle washing machine (1884) and the invention of the cork sealed bottle cap (1891) radically increased both use and scale.

Busch was also the first brewer to pasteurize beer. Pasteurization calls for heating the beer (and the bottles) to just below the boiling point to kill bacteria. This improved the longevity of the beer as it shipped and also made production more reliable and consistent. Finally, Busch was the first to use a refrigerated rail car for shipping (1874). These were packed at the ends with ice, but they did keep beer cool on the long trips to the southwest. Shortly, mechanically refrigerated cars would be available. By 1879, Busch had expanded well beyond his original strategy and was shipping beer to every state in the Union as well as Japan, England, France, Germany and to countries in Central and South America (Ogle, 2006). 
Shipping brewers quickly adopted these innovations and developed their own such as the depots at major railheads, filled with ice and designed to store beer until it could be distributed locally. Their beers were soon competing effectively with home town brewers. In fact, the reliability and quality of the shipping brewers' products was placing significant pressure on those smaller firms who could compete only by dropping prices. However, the automation of brewing had continued apace and the large brewers had mechanized grain transport, malting towers capable of handling vast quantities of barley at one time, large brew kettles, huge, refrigerated lagering caverns and highly efficient packaging lines. For example, Pabst's bottling lines were so large that the bottle washing machine had 96 spindles, each processing 75,000 bottles per hour. Technological changes like these drove the minimum efficient scale of production in brewing to about 100,000 barrels per year by the 1890's.

Shipping brewers weren't the only firms attaining this size. Firms in large metropolitan areas like New York and Philadelphia were able to adopt most of the production technologies and were among the largest in the country until the 1890's. In 1884, Best Brewing was in a virtual tie with Hell Gate Brewing of Brooklyn at just over 200,000 barrels while the Bergner and Engle Brewery of Philadelphia and Schlitz Brewing were just behind them. Anheuser-Busch produced 141, 000 barrels that year. On the other hand, the number of breweries had dropped to roughly 2200 , of which half produced less than 1,000 barrels and three-quarters less than 4,000 barrels per year (Stack, 2000). The cost of production differences were growing.

Supply problems and shifts in customer preferences also affected how beer was made in this era, with effects that persist today. The growth of industry output (per capita consumption increased from 3.4 gallons to 15 gallons over the 1865-95 period) and poor harvesting conditions had placed pressure on the use of six-row barley, the American standard. Moreover, consumers were seeking lighter and lighter beers. Six -row barley was high in protein and the lighter the color of the beer, the more likely unattractive globs of the protein or haze would be evident. Thus, American brewers began searching for adjuncts or replacement starches that could be brought into the brewing process. Yellow corn didn't work as the oils turned the brew rancid. It turned out that rice and white corn would work, but adding them was costly - but the changes in consumer tastes helped overcome the differential.

The lager beer introduced by German immigrants was called the Bavarian style to contrast it with a more recently developed (1840's) Bohemian lager. Inasmuch that Bavarian style beer had caught on in the U.S. because of its comparative lightness, Bohemian beer was even lighter and more effervescent. Original versions were brewed in the city of Pils (hence the name Pilsner) and the style won international acclaim at the Vienna International Exposition of 1873. American brewers began experimenting to try and replicate the style with domestic ingredients and it was found that a very acceptable version could be created with the use of white corn and rice as adjuncts - and sold for a premium price.

The most famous of these beers was the product of a partnership between Adolphus Busch and an importer named Carl Conrad. Conrad wanted a beer that would be distinctive in an increasingly crowded field and he wanted it to taste like a beer both he and Busch had tried before, from a small town called Budweis where the brew was called "the beer of kings". Although Busch ended up using American grains (including rice) he also specified distinctively flavored Saaz hops and a particular yeast from Bohemia. Busch also lined the aging vats with beechwood strips to capture yeast and impurities and make a cleaner beer (Ogle, 2006).

Budweiser was immediately successful. Conrad sold 250,000 bottles in 1876, the first year of production. From 1876 to 1882, 20 million bottles were sold. Competitors paid attention and Conrad and Busch fought a number of legal actions against brewers both large and small who sold beer under the Budweiser name, including Miller Brewing. (Anheuser-Busch ended up pursuing similar litigation until the 1970s: a small Pennsylvania brewer named Dubois Brewery produced Dubois Budweiser until 1972 (Grace, 2005)). Partially, competitors construed the Budweiser name as a style (the way Pilsner is in the style of Pils) but there was no doubt that many were riding the coattails of Busch's success. Conrad eventually went bankrupt and sold the rights to the Budweiser label back to Busch in 1883 in settlement of debts.

By the late 1890s, the brewing industry was composed of a decreasing number of small, independent breweries, some middle tier breweries owned as investments by outside groups (the British were particularly prevalent in this) and the large shipping breweries, Pabst (formerly known as Best Brewing), Anheuser-Busch, and 
Schlitz were far and away the largest American firms and were, in fact, the three largest breweries in the world and Pabst was nearing the one million barrel per year output level.

\section{THE "NOBLE EXPERIMENT" OF PROHIBITION: 1900-1932}

\section{"Prohibition makes you want to cry into your beer and denies you the beer to cry into." (Don Marquis)}

"I believe this would be a good time for a beer." (Franklin Delano Roosevelt at the signing of the 21st Amendment)

Prohibition as the law of the land in the United States lasted from the implementation of the $16^{\text {th }}$ amendment on Jan 16, 1920 until President Roosevelt signed off on revisions to the Volstead Act (the enforcement mechanism for Prohibition) on Mar 23, 1933. However, the factors driving Prohibition had been at work for decades and well before 1920 many states, counties, and cities had already implemented restrictions on alcohol sales and consumption. Nor did the desire to restrict or control alcohol end with the repeal of the $16^{\text {th }}$ Amendment: even today, social attitudes toward alcoholism, drunk-driving, and the like have been characterized as "neo-Prohibition".

Until the 1840's, beer played little role in U.S. alcohol production or consumption for several reasons. Beer production wasn't suitable everywhere: for example, the climate in the southern states was too warm so beer was not an important beverage. In addition, even in the North, the labor needed to produce beer inputs like barley was deemed better used in more substantial food crops. Settlers often planted low maintenance apple and pear trees as the necessary inputs to (hard) cider and perry (the pear based equivalent of cider) as alternatives. Another factor was that molasses from the Caribbean was easily converted to rum. Finally, after the Revolution and the westward expansion into the Ohio Valley area, over-production of grains like corn and rye made distilling whiskey very feasible. In short, America of the early $19^{\text {th }}$ century was a hard-drink (and hard drinking) society: "Americans' appetite for spirits stupefied and astounded foreigners. "I am sure", wrote an English visitor, "the American can fix nothing without a drink. If you meet, you drink; if you part, you drink...they quarrel in their drink, and they make it up with a drink"' (Ogle, 2006, p. 23). Put differently, in the early part of the century, there were about 200 ale brewers but over 14,000 distillers.

In the 1820s, the so called Second Great Awakening, a broad based religious movement, focused attention on a number of social ills, including drinking. Alcohol consumption was argued to lead to murder, prostitution, and gambling, to destroy marriages and families, and to crush initiative and ambition. Drink was positioned as a threat to the future of the country. This was a very effective platform as millions pledged abstinence from alcohol and a number of states and territories (Maine and Vermont leading the way) passed legislation to make it the rule for all. Still, the initial impetus for ending drink foundered on a number of factors. First, one of the other major social issues in this movement was abolition or the end of slavery. This assumed increasing prominence in the national discourse and ultimately diverted much energy from the temperance drive. Second, the passage of such draconian liquor laws spawned violent resistance with lethal riots occurring in Chicago and New York. There was the sense that the antialcohol movement had gone too far, too fast. Third, the massive immigration of Germans in the 1840's and '50s and the subsequent emergence of the German brewing tradition here was a direct repudiation to the more lurid claims of the temperance advocates. Germans brewed and drank beer copiously and yet were industrious and responsible, good citizens and good family people. Beer advocates argued this was because lager beer was not intoxicating (i.e., not alcohol in the sense the temperance people meant) and was in fact a wholesome and invigorating beverage. Finally, the Federal government had been applying excise taxes on alcohol sales and beer provided significant support to budget and expenditures.

The second round of the Temperance movement began roughly in the 1880's. Again, the drivers were social issues but now were arising from the increasingly rapid pace of industrialization and urbanization of American society. These were accompanied by increased poverty, deplorable working conditions, over-crowding in apartments and tenements, exploitation of workers, and overall corruption. Reformers of all sorts were motivated to attack these problems (such as child labor, food and water purity, truth in advertising, public health, a minimum wage, or the ends of patronage based political jobs); a number of groups such as the Women's Christian Temperance Union and the Anti-Saloon League (ASL) emerged to combat drink which was viewed as exacerbating the other problems. In particular, the tactics of the ASL were effective in tipping the argument toward prohibition. The ASL 
didn't focus so much on banning alcohol as much as cleaning up towns by eliminating the outlet. By positioning the saloon as iniquitous and a source of disease and depravity, the ASL made it difficult to publicly support drinking establishments. This, and other efforts focusing on local choice and electing anti-alcohol politicians, was effective: by 1909 , about half the U.S. was under some form of dry or prohibition law. This was particularly important for brewers because they typically owned or operated the saloons and because beer consumption had soared while stronger liquor drinking had declined. Now, rather than being the healthful alternative to whiskey, beer was the target.

At the end of the Prohibition drive, World War I and anti-German sentiment became an organizing focus. To begin, the war imposed some production problems and the use of barley for beer rather than bread was portrayed as unpatriotic. In addition, most brewers were of German extraction. Supporting beer, by implication, supported Germans and Germany. A former lieutenant governor of Wisconsin (home of most of the largest American brewers at the time), John Strange, claimed that "the worst of all out German enemies, the most treacherous, the most menacing, are Pabst, Schlitz, Blatz and Miller" (Ogle, 2006, p. 173). Members of the Busch family (owners of Anheuser-Busch) were described as enemy agents and spies. Brewers were also accused of purchasing and using newspapers to spread propaganda for the Germans. None of these accusations could stick, but they did color the conversation. In early 1919 , the last state required for ratification of the $16^{\text {th }}$ Amendment passed the bill. With respect to the industry, the law was only adding insult to injury as the temperance pressures and changes in local laws had reduced the number of brewers to near 500 .

Many brewers survived by turning to related businesses such as baking yeasts or malt syrup. Almost all produced some form of near beer (about $1 / 2 \%$ alcohol content). Some produced soft drinks (both Anheuser-Busch and Pabst were in this business) or dairy products (Pabst again, for example, but also the Yuengling family which actually stayed in the ice-cream business until 1985). Most also sold off other assets such as real estate. Still, this usually was not enough to keep the doors open. By the end of Prohibition, fewer than 200 brewers were still functioning firms.

In 1928, as he prepared to run for the Presidency, Herbert Hoover called Prohibition a "noble experiment" but even then, it was creating difficulties and backlash. The primary reason was that making alcohol illegal had created a new, lucrative, and dangerous criminal class which smuggled alcohol in from Canada, particularly across Lake Erie, and from the Caribbean. Most of this was hard alcohol (beer being too low in alcohol by volume to be really profitable). Speakeasies or illegal saloons sprang up and not all were hidden. Illegal distilling in the Appalachians increased dramatically. The perceived flagrant disregard for the law was due in part to a notably understaffed enforcement agency, the Prohibition Bureau, which never had more than 3,000 agents. An additional blow to Prohibition came with the Great Depression and the affiliated unemployment. The Federal government had long since switched revenue streams from excise taxes on alcohol to income tax but the radical increase in unemployment meant that new revenue streams would be essential. By the early 1930's, the Democratic Party had made repeal part of its platform and Roosevelt carried through on this almost immediately upon taking office.

Even so, this was not a return to business as it had been practiced. Among the most significant regulatory changes was the termination of the "tied house" or brewer owned tavern. The Federal Alcohol Administration Act of 1935 established the three tier system of brewer, distributor, and retailer that we see today. More important, though, were the changes in taste and technology that had taken place in American society.

Nor did social concerns that led to Prohibition disappear although the approach has changed. The emphasis over the past several decades has been on controlling consumption ("responsible drinking") rather than completely eliminating it. This has come from public and private institutions that study alcoholism (a term that only since Prohibition has entered the lexicon) and have developed programs to control it. Other private groups have taken on drinking as well, such as Mothers Against Drunk Driving or the National Parent-Teacher Association. The effect has been realized in federal legislative changes that increased the legal drinking age to 21 in 1984 (the U.S. is very nearly alone in this: virtually all countries have established 18 as the minimum legal age (Hanson, 2009)), reduced the maximum allowable blood alcohol content level to $.08 \%$ in 1998, and limited tax deductions for alcohol at meals. As baby boomers age, values have changed as well. Alcohol consumption during working hours is almost universally frowned upon, and the pursuit of healthy lifestyles has reduced alcohol consumption. In a very real 
sense, Prohibition was just a specific phase in an ongoing American conversation about personal rights and obligations and the nature of the moral life.

\section{THE NEW AMERICAN BREWING COMPETITIVE LANDSCAPE: 1933-1990}

In 1933, the year the Volstead Act was repealed and beer could be legally produced again, the number of brewers was around 200 though by year end had risen to a little over 300. Just one year later, though, over 750 brewers were in business and the total hit a peak in 1935 at 766 that wasn't exceeded until the 1990s. In fact, until the 90's, the population of brewers declined every year (McGahan, 1991).

The reasons for the initial surge in numbers are straightforward. Immediately, orders exceeded capacity for many brewers because it took time to ramp up from alternative projects (such as producing soft drinks or ice cream). This opened opportunities for new local brewers to enter. In addition, there seems to have been quite a few unscrupulous (or incredibly under-qualified) owners called "Wall Street" brewers who had snapped up assets of failed breweries at minimal cost. Once production was legal, they quickly solicited investment and started brewing. However, their lack of skills made for some very bad if not dangerous brew (Ogle, 2006).

After 1935, the brewery population dropped quickly. The post-Prohibition environment was very different from that of the years just before the Amendment was passed and these factors drove decades of consolidation.

One reason was that Prohibition had, in fact, been successful in terms of changing Americans' consumption patterns. Per capita beer consumption dropped from a high of about 21 gallons per person per year in 1914 to less than nine in 1933. Nor was demand likely to increase much soon: soft drinks had emerged as a strong substitute and consumer preferences for them stayed strong. Moreover, even though there was no Federal law prohibiting beer, local prohibition laws were widely implemented, particularly in the South. By some estimates, per capita consumption of beer didn't reach pre-Prohibition highs until the 1970's. In the short term, the brewing industry faced excess capacity problems which placed enormous cost pressures on inefficient brewers.

Other changes in consumption patterns also affected brewer survival. Prior to Prohibition, most consumption had taken place in taverns and saloons so the packaging was typically in wooden kegs. In the 1930's, the bias against saloons that had been a driver of Prohibition persisted, and consumers had switched to preferring to drink at home. In part, this was made possible because of two technological advances. First, mechanical refrigeration had penetrated the market rapidly. Prior to 1920, less than $1 \%$ of U.S. homes had a refrigerator but by 1933, that number had grown to 25\%. Second, advances in packaging, particularly the development of the steel beer can (in 1935 and introduced by Krueger Brewing) helped amplify the home consumption trend. Small brewers often had difficulty with the capital cost of building canning lines and so faced significant demand constraints.

These forces (slack local demand and the control of packaging technology like can, bottle, or steel kegging lines) led to the increased prominence of "shipping" brewers. Larger brewers such as Schlitz, Anheuser-Busch, Pabst, and others had been shipping beer for decades but the development of a motorized delivery trucks, better roads, and large scale refrigerated storage facilities - and changes in the legal rights of brewers to forward integrate changed how distribution was done. Just as the development of rail had expanded potential markets, new trucks and roads vastly expanded the serviceable area for brewers as they had previously been constrained to sites on the rail system. In addition, trucks and roads decreased the cost of distribution. Brewers also began to build up networks of distributors (the new rules of the game prevented ownership of retail outlets for brewers so distributors became the most cost effective way to reach them) in an expanding, regional way. The changes in packaging complemented these moves as canned beer and steel kegs were much more cost effective to ship. Shipping brewers were still almost always Midwestern firms as brewers in the East and in California usually had large enough metropolitan areas to support their businesses without reaching out.

Still, shipping over distance created costs for brewers that local brewers didn't incur. Shippers addressed these cost differentials in several ways. One was through continued improvement in production and packaging technologies. The minimum efficient scale (MES) for brewers had reached 100,000 barrels per year by 1877 but had not increased by the 1930's (McGahan, 1991). Nonetheless, in-line improvements had increased the cost penalty for 
not being at scale. These improvements included deployment of refrigeration and recycling technologies that produced a more consistent beer and reduced the need for post-brewing pressurization processes. Thus, technologically advanced shipping brewers could overcome part of the cost penalty of transportation through production efficiencies. Another tactic was to embrace the cost difference and charge a higher price. Shipping brewers preferred to do this because the consistency of their beers made them a premium product versus the more irregular quality local brews, called popular beers. Also, large brewers were wary of being too aggressive with pricing and driving local brewers out of business since one of the motivations for the repeal of Prohibition was increased employment. Aggressively driving local brewers out of business might have had adverse political consequences.

By the end of World War II, per capita consumption had increased by about $50 \%$ to 19 gallons in part because distilling had been severely curtailed during the war and beer drinking picked up as a substitute. Shipping brewers had augmented their strategy by opening up satellite breweries either through acquisition (preferred because it also provided access to the target brewer's distribution network) or new plant development. This became possible because the advances in brewing technology assured that local differences in water wouldn't adversely affect the taste of the beer. By 1946, firms such as Pabst, Schlitz and Anheuser-Busch had expanded into the New York metropolitan area with secondary breweries. Yet, after the war, beer demand leveled off then declined for the next fifteen years due in part to the resurgence of distilled spirits (per capita consumption increased significantly) but more importantly from demographic shifts. Beer was primarily consumed by younger men (20-40 years) and the size of this group was sliding toward a historic low (Ogle, 2006). Between these changes and the expansion and better utilization of existing facilities (not to mention an increase in MES to about one million barrels per year), the industry was again faced with surplus capacity. This led to price wars that drove additional geographic expansion (into Western markets and Florida), exit and consolidation. The concentration for the top five brewers increased from $21 \%$ in 1947 to about $31 \%$ in 1958 and the top brewers were now established as national firms (McGahan, 1991). Table 1 illustrates the dramatic changes in industry concentration up through 2005.

The increasing concentration trend persisted into the 1970's, but for somewhat different reasons than before. Since the 1950's, brewers had been converging toward a standard style American lager beer that deemphasized hoppiness and malt flavors in response to general shifts in American tastes toward a blander diet (Choi and Stack, 2005). Miller Brewing, for example, benefitted greatly from this as the Miller High Life recipe was right in line with these emerging preferences. On the other hand, as brews came to taste more and more alike (due both to convergence and improvements in processing that even smaller brewers could attain), the value of a premium label began to disappear and the industry saw a temporary resurgence of the mid-tier brewers who were able to gain ground by holding to a lower price point. Larger brewers responded by significantly increasing marketing expenditures, following the Procter and Gamble path of market and customer segmentation. Brewers bought or sponsored sports teams and events, explored advertising in established media (such as magazines and radio) and television. Miller, in resurrecting the High Life label, focused on women's magazines such as McCalls and Vogue. The ratio of expenditures to sales shot up rapidly: from less than 1\% around WWII to 6-10\% as a percentage of sales by the 1970s. National brands in all sorts of consumer goods were gaining power and this kept an almost unsustainable pressure on small brewers to keep up.

Table 1: Top Ten brewers 1950-2005 (Source: Beer History, 2007)

\begin{tabular}{|c|l|c|c|l|c|}
\hline $\mathbf{1 9 5 0}$ & \multicolumn{1}{|c|}{ Brewer } & Share (\%) & $\mathbf{2 0 0 5}$ & \multicolumn{1}{|c|}{ Brewer } & Share (\%) \\
\hline 1 & Jos. Schlitz Brewing & 6.08 & 1 & Anheuser-Busch & 49.5 \\
\hline 2 & Anheuser-Busch & 5.83 & 2 & Miller Brewing & 18.7 \\
\hline 3 & Ballantine, Inc. & 5.22 & 3 & Molson-Coors Co. & 11.1 \\
\hline 4 & Pabst Brewing Co. & 4.90 & 4 & Pabst Brewing & 3.4 \\
\hline 5 & Schaefer Brewing & 3.16 & 5 & Yuengling \& Son & 0.8 \\
\hline 6 & Liebmann Bros. & 2.73 & 6 & Boston Beer & 0.7 \\
\hline 7 & Falstaff Brewing & 2.51 & 7 & City Brewery & 0.5 \\
\hline 8 & Miller Brewing & 1.26 & 8 & Latrobe Brewing & 0.5 \\
\hline 9 & Blatz Brewing & 0.81 & 9 & High Falls Brewing & 0.3 \\
\hline 10 & Pfeiffer Brewing & 0.80 & 10 & Sierra Nevada & 0.3 \\
\hline
\end{tabular}


Some responded by merging with other firms to attain scale benefits. Alternatively, and in the usual 1950s and ' 60 s way, many brewers merged with or acquired unrelated partners. For example, some brewers purchased olive oil producers, or a parts manufacturer for computers, or mining companies or fishing fleets. Still, most deals were within the industry and this process reduced the number of brewers. The most well known acquisition of the period was that of Miller Brewing by W.R. Grace, a very large conglomerate in 1966.

Just a few years later, Grace sold Miller to Philip Morris (PM). The marketing moves introduced by the PM management team significantly changed competition in the brewing industry in the 70's. First, PM greatly increased national advertising for Miller and improved Miller's sales dramatically. Then, PM issued in the period of rapid product line extensions. Until then, brewers had generally focused on one or two beer labels. Demographic and taste changes were about to alter this. Americans were becoming more health and weight conscious and the brewing industry responded. Rheingold Brewing had introduced a new style "light" beer called Gablingers but the product flopped. Miller followed up by introducing Miller Lite in 1975 and with it the largest ad campaign in the history of the industry (Mittelman, 2008). The success of Lite eventually drove other brewers to introduce competitive labels and some also developed super-premium beers such as Michelob or Lowenbrau. The Miller management envisioned overtaking Anheuser as the nation's top brewer and in fact, Miller did grow substantially, but this was in large part by taking share away from former leaders such as Schlitz and Pabst.

The final major shift in the industry at this time was the emergence of Adolph Coors Brewing as a major player. Coors had been brewing since the 1870's in Colorado and by the standards of other brewers was something of an oddity in its degree of vertical integration and its brewing process. Coors produced only one beer and used "cold-filtering" rather than pasteurization to improve product life. However, this required strict control over temperatures (near freezing throughout) and therefore distribution (eleven states in the West). Coors' production methods intersected the drive toward the "real and sincere" movement in personal consumption (see below in Craft Brewing for a more detailed explanation) and Coors suddenly became famous as a "pure" (as in the spring water) beer. According to Maureen Ogle, some advocates went so far as to claim that Coors was "the Chateau Haut-Brion of American beers" (Ogle, 2006, p. 274). Sales rocketed and Coors moved from $12^{\text {th }}$ largest brewer to fourth by the early 70's and third by 1980 .

\section{GLOBAL CONSOLIDATION VERSUS THE RISE OF THE SMALL BREWERS: 1990-2010}

The last two decades have seen two disparate trends in place. On one hand, brewing is increasingly controlled by a small number of global firms, most recently reflected in the acquisition of Anheuser-Busch by InBev. Table 1 shows the changes in market control among the top ten brewers between 1950 and 2005. The period has also seen a remarkable shift in the U.S. industry with the emergence of micro or craft brewers which have come to be the most discussed (albeit still small) segment of the industry.

Up until 2004, A-B was the largest brewer by volume in the world in an industry characterized by fragmentation and national brand champions. On a global level in 1996, the top four brewers controlled just $20 \%$ of the market. Contrast this with soft drinks (78\%), household goods $(75 \%)$ or tobacco $(60 \%)$. The real concentration in the brewing industry emerged at the national level where share controlled by the top three brewers in mature economies was generally in the $70 \%$ and up range (Benson-Armer, Leibowitz, and Ramachandran, 1999). Exceptions to this included Germany and China, where local preference persists (which is why SABMiller operates 64 breweries in China). However, these mature markets were slow to no growth markets. In the U.S., for example, growth had flattened since 1980 (see Figure 2). Increasingly, the opportunities for growth were perceived to be Asia (particularly China), Latin America, and Russia. This was occurring for several reasons.

First, these markets were not traditionally beer drinking cultures but increasing affluence had begun to alter this. Growth in Asian markets, for example, had been 6-10\% over the 90's with no real reason to expect a change. Second, steep reductions in tariffs as a result of trade liberalization had made the price of imported goods much more competitive with domestic products. Third, customer preferences in beer were converging in ways that favored lagers and canning over ales and bottling. Finally, global brands were taking hold. This led to an initial race from the mid-90's to snap up domestic brewers and build brand through them. 


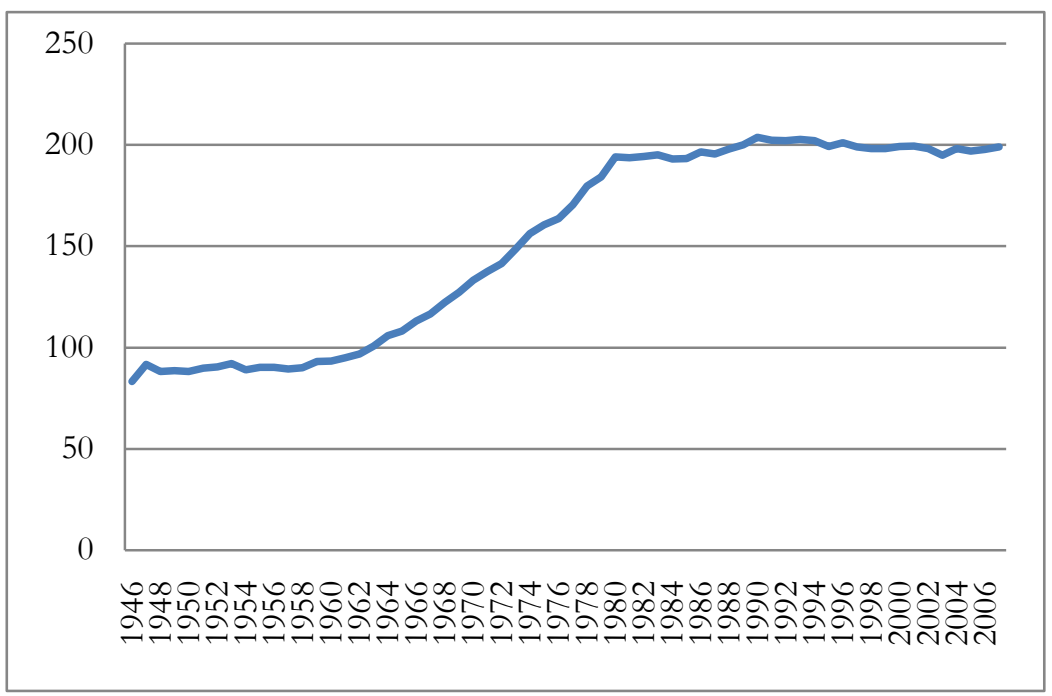

Figure 2: Beer Production 1947-2007 (MM BBL) (Source: Beer Institute, 2009)

Major players in this strategy included Heineken, South African Brewing, Interbrew, AmBev, and Fosters. Heineken, for example, expanded through Eastern Europe after the fall of the Soviet Union, picking controlling interest in breweries such as Krusovice and Zywiec in Poland, BBAG in Austria, Volga Brewery, Shikhan Brewery, and Patra Brewing in Russia and many others. The company had also purchased or taken stakes in breweries in Costa Rica, Panama, Nicaragua, and Chile as well as Middle Eastern breweries in Lebanon and Egypt. Heineken also purchased the leading Spanish brewer Cruzcampo from Diageo (the firm formed from the merger of Guinness and Grand Metropolitan in 1997). The company has also established a significant presence in Asia with breweries in China, Vietnam, Malaysia, New Zealand, among others (Dow Jones, 2004; Dow Jones, 2005; Devaney, 1998; DowJones, 2003; Ragahvan and Johnson, 1999). For a partial list of Heineken brands (see Table 2).

South African Brewing ( $\mathrm{SAB}$ ) focused initially on penetrating markets in Africa and Asia. This move began in the early 1970s after consolidating most of the brewing industry in South Africa. Initially, SAB acquired control of brewers in nearby countries in southern Africa such as Swaziland, Botswana, and Lesotho. In 1993, SAB made its first foray into Eastern Europe, acquiring the Hungarian brewer Drehar. The firm followed this with acquisitions in Poland, the Czech Republic, Romania, Slovakia, and Russia over the next five years. SAB also developed joint ventures in China and acquired the Foster brand and facilities in India in 2006 (SAB Miller, 2009). For a partial list of SAB brands (see Table 1).

Similarly, in this period, Interbrew of Belgium focused on developing a portfolio of specialty and regional beers such as Stella Artois, Hoegaarden, Labatt's, Rolling Rock, and nearly 200 other labels (du Bois, 1996). For a partial list of AB InBev's brands (see Table 2).

In contrast, American brewers made relatively small moves in these directions. In 1993, A-B purchased an $18 \%$ stake in Grupo Modelo, brewer of Corona that was ultimately expanded to about 50\%. Modelo has been selling Budweiser in Mexico since the late 1980's and that relationship was expected to continue (Gibson, 1993). Also, in 1995, the company purchased control of Budweiser Wuhan in China. Miller Brewing, a division of Philip Morris, acquired a $20 \%$ stake in Molson Breweries in 1993. More decisively, Adolph Coors Co. purchased the English brewer Carling from Interbrew in 2001 for $\$ 1.7$ billion. The product line included Carling as the top selling beer in England and three other brands which amounted to a $19 \%$ market share, second highest in the U.K., and four breweries (RealBeer, 2001). In 2004, Anheuser-Busch made its most substantial move by acquiring Harbin Brewery Group to complement its Wuhan operations. 
Table 2: Selected Global Brands

\begin{tabular}{|c|c|c|}
\hline Heineken & SABMiller & AB InBev \\
\hline “33” Export & Aguila & Alexander Keith \\
\hline Amstel & Blue Moon & Antarctica \\
\hline Anchor & Castle Lager & Baisha \\
\hline Bavaria & Club Colombia & Bass \\
\hline Bintang & Coors Light & Becks \\
\hline Birell & Dreher Classic & Boddingtons \\
\hline Buckler & Gambrinus & Bohemia \\
\hline Edelweiss & Grolsch & Bozicno \\
\hline Escudo & Haywards 5000 & Brahma \\
\hline Fürstenberg & Imperial & Budweiser \\
\hline Gold Crown & Miller Genuine Draft & Castlemaine \\
\hline Havannah & N'GOLA & Dommelsch \\
\hline Heineken & Peroni Nastro Azzurro & Double Deer \\
\hline Kaiser & Pilsner Urquell & Franziskaner Hefe-Weissbier Hell \\
\hline Kalik & Snow & Haake-Beck \\
\hline Karlovacko & St Louis & Harbin \\
\hline Kilkenny & Tyskie & Hertog_Jan \\
\hline Maccabee & Velkopopovický Kozel Premium & Hoegaarden \\
\hline Murphy's Irish Stout & Zolotaya Bochka Klassicheskoye & Jinling \\
\hline Ngok & & Kamenitza \\
\hline Rosario & & Klinskoye \\
\hline Sakara & & Labatt Family \\
\hline Salta & & Lakeport Pilsener \\
\hline Santa Cerva & & Löwenbräu \\
\hline Starobrno & & Murphy's \\
\hline Stolichno & & Oranjeboom \\
\hline Windhoek & & Red Shiliang \\
\hline Zagorka & & Sibirskaya Korona \\
\hline Zipfer & & Skol \\
\hline \multirow[t]{4}{*}{ Zlaty Bazant } & & Spaten - Original Munich Beer \\
\hline & & St.Pauli Girl \\
\hline & & Staropramen \\
\hline & & Stella Artois \\
\hline
\end{tabular}

Sources: AB InBev: http://www.ab-inbev.com/go/brands/brand_portfolio/local_brands/franziskaner_weissbier.cfm

SABMiller: http://www.sabmiller.com/index.asp?pageid=1422

Heineken: http://www.heinekeninternational.com/products_brands_brands.aspx

In the second phase of consolidation, global brewers began to focus on deals between peers rather than penetration into new markets through acquisition of smaller brewers. The first move was by South African Breweries (SAB) when it purchased Miller Brewing from Philip Morris for about \$5 billion in 2002. The move was driven by the need to develop revenues in US dollars versus the depreciating South African rand and to gain access to Miller's American distribution network, which would help the growth of SAB's recent purchase of Pilsner Urquell. The deal vaulted the newly named SABMiller into the global number two position in terms of annual volume, behind Anheuser-Busch. Two year later, Belgium's Interbrew and Brazil's AmBev announced plans to merge operations. This deal between the third and fifth largest brewers in the world would move them to number one in total brewing volume, displacing Anheuser-Busch. The new merged firm became known as InBev (Samor and Bilefsky, 2004).

Also in 2004, Adolph Coors Co. and Molson Brewing of Canada initiated merger discussions. The firms had been cooperating in cross marketing since 1998 but major differences in control over their respective markets (Molson was the largest Canadian brewer and controlled about $40 \%$ of the market while Coors was a distant third in the U.S. market with $11 \%$ share) led to a protracted battle among Molson shareholders. Moreover, since this was positioned as a merger of equals with no premium to Molson shareholders, Molson's institutional investors broadly 
opposed the deal, one investor arguing that while this made the new firm larger, on a global scale it wasn't large enough. Many supported a potential counter bid from Ian Molson, a disaffected family member and major share holder. The dispute dragged on until February, 2005 when shareholders finally approved the merger. Throughout this, SABMiller had been engaged in discussions with Ian Molson and late in the process sparked rumors that it was going to offer a counterbid of its own (Berman and Frank, 2004; Chipello and Frank, 2004; Frank, Lawton, and Chipello, 2005; Carter, 2005; Chipello and Lawton, 2005).

Two years later, SABMiller and Molson Coors reached an accord on a joint venture for the United States and Puerto Rico called MillerCoors. This venture would push combined share for the firms to about $30 \%$ and annual revenues to $\$ 6.6$ billion. Deal benefits were predicated on combining the geographically complementary systems of the two firms to achieve economies in brewing, distribution, and transportation that were estimated to reach $\$ 500$ million per year (Philips, 2007; Kesmodel and Ball, 2007).

In the most recent (and largest) move, InBev's bid for A-B broke on June 12, 2009, with an offer of $\$ 65$ per share or a premium of $35 \%$ to Anheuser-Busch's 30 day stock price average. The motivations included access to distribution in the U.S. for InBev and negotiating power over inputs. InBev was very strong in Europe and Latin America but marginal in North America and Anheuser-Busch was just the opposite. Both had operations in China. InBev's CEO Carlo Brito argues that the new firm could also gain some restructuring benefits through selling off theme parks and division that makes cans and bottles. Another possibility was reduction in advertising and marketing. Anheuser-Busch spends about $\$ 500$ million in ads and $\$ 300$ million in sport sponsorship per year though some analysts argue that in a flat market, this move could also trim sales. On the other hand, A-B's brewery operations were already the most efficient in the industry and the lack of market overlap made economies of scope through joint transportation or production difficult. Nor was restructuring benefits through closing plants perceived as feasible (Economist, 2008a, 2008b, 2008c); Foust, Ewing, and Smith, 2008; Kesmodel and Kamitsching, 2008; Vranica and Kang, 2008).

Initially, this bid met with a great deal of resistance from the Busch family members on the board, St. Louis and Missouri politicians, and from "patriotic beer lovers" (Economist, 2008c) manifesting protectionist concerns. A-B's executives described the bid as undervalued and proposed as an alternative, stock price strengthening moves such as selling the theme parks and the bottling/canning business for a combined $\$ 4.5$ billion as well as implementing cost cutting measures that could save $\$ 750$ million to $\$ 1$ billion per year (Kesmodel, Kamitsching, and Cimilluca, 2008). A-B also tried to purchase the portion of Mexican brewer Modelo that it didn't already own (about 50\%) as this could have made the firm too large to swallow. However, this plan fell through and in mid-July, InBev sweetened the deal to $\$ 70$ per share or $\$ 52$ billion. The A-B board capitulated. By November, 2008 shareholders from both firms had approved the deal and United States Department of Justice had also granted approval.

InBev moved quickly to create a new cost-conscious environment in St. Louis. Anheuser-Busch had been long known as one of the best employers in the area. For example, employees typically received two cases of beer per month, the firm lavished tickets to the baseball Cardinals across the firm, and executives were accustomed to first class travel and accommodations. Now, even before the deal had completely closed, 1,400 employees (about $6 \%$ of the workforce) were laid off. By January, 2009, it had suspended retiree life insurance and plans to stop contributions to company pension plans by 2012. InBev put the fleet of A-B corporate jets on the market, slashed planned marketing expenditures for the Vancouver and London Olympics, and reduced new ad development significantly. In addition, InBev has changed the relationship with vendors by extending the terms on accounts payable to 120 days from 60 or fewer (Kesmodel and Vranica, 2009; Dalton, 2009).

\section{CRAFT BREWING GROWTH}

"Nothing quenches the thirst like a Wheat Beer, or sharpens the appetite like an India Pale Ale. Nothing goes as well with seafood as a Dry Porter or Stout, or accompanies chocolate like an Imperial Stout. Nothing soothes like a Barley Wine. These are just a few of the specialty styles of beer." (Michael Jackson, the Beer Hunter, 1942-2007) 
Small scale brewing in the United State is often described as "micro-brewing" but that term has some quite specific scale connotations and "craft brewing" is a more general term. According to the Brewers' Association, craft brewers can be defined as those who focus on traditional styles or beer (such as an all-malt flagship beer), are independent (less than $25 \%$ equity controlled by an alcoholic beverage industry firm that is not already a craft brewer) and are relatively small (less than 2 million bbl per year production) (Brewers Association, 2009a). From a scale perspective, the industry exhibits five or six segments. Microbrewers are firms that produce less than 15,000 barrels per year. Brewpubs are also small and sell at least $25 \%$ of the beer they produce on site (usually through a restaurant/ pub environment). Regional brewers are those that produce between 15,000 and 2 million bbl per year. These can be either craft brewers (like Sierra Nevada or Boulevard Brewing of Kansas City) or standard lager brewers. Large (also called national) breweries are those with over two million barrels of production per year. Finally, a contract brewer is a firm that hires another to brew for it, either on a complete basis or as a supplement to existing production facilities (Market Segments, 2009). The growth of craft brewing in the U.S. has been remarkable. In the mid 1980's, the number of breweries in the country reached an all time low (41 firms running 89 breweries) with the industry being divided into two sets: national brewers (some successful, some failing) and regional brewers, almost all of which were increasingly in economic straits. Since that time, the number of breweries has exploded to over 1,500 (see Figure 3). Given that the brewing industry exhibits concentration characteristics of maturity, what factors account for the dramatic change? There are likely a number of causes, both regulatory and demographic.

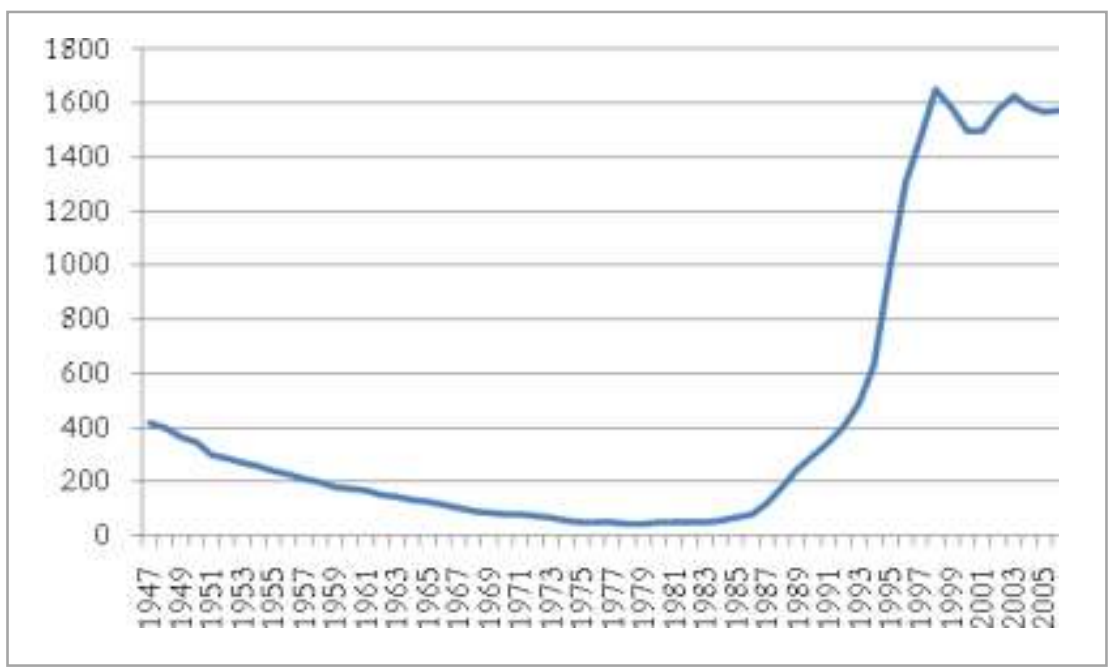

Figure 3: Brewery Population, 1947-2007

(Source: Beer Institute, 2009)

The prototype for the small brewer of the last two decades is probably the Steam Beer Brewery of San Francisco. Fritz Maytag (of the appliance Maytags) took an interest in and then sole control of this very old brewery which first opened in 1896 to make a peculiarly West Coast style lager. The brewery had limped along for several decades on the verge of failure, mostly because it made very bad, sour beer. Maytag took control of the brewery in 1969 and changed the strategy to emphasize ingredients such as European two-row barley and whole hops. He also understood that the small scale of the brewery meant that it would never be cost competitive with the large brewers. However, the local market was already open to higher priced beers from Europe so the newly named Anchor Brewing would stay small but dedicated to traditional brewing arts - at a premium price point. Within a few years, Anchor Steam was regarded as one of the best beers available and a sign that a small brewer could thrive (Ogle, 2006).

At about the same time (1978) President Carter repealed a regulatory artifact of the end of Prohibition that outlawed home brewing. This was perhaps more bowing to the inevitable as home brewing had never really died and 
was, in fact, becoming very popular on both coasts. Still, the repeal spawned a tremendous growth in the hobby as brewers could now acquire malted grains, yeasts and hops that let them create or replicate beer styles that were not possible to purchase. The skills that many home brewers developed in the garage or basement provided the technical foundation for the next step: commercial brewing. Jack McAuliff was an early home brewer (when it was still technically illegal) and went on to start New Albion Brewing, usually described as the first real microbrewery. While New Albion failed fairly quickly, it was at about the same time that two other home brewers - Ken Grossman and Paul Camusi - started up Sierra Nevada Brewing which ranked in 2009 as one of the top ten brewers in the U.S. Again - home brewers Michael Laybourn and Norman Franks started Mendocino Brewing in the late 1970s. This startup in Hopland, CA is notable because it was the first brewpub. Mendocino is still brewing beer.

The growth of "lifestyle" based consumption in the 1970's and " 80 s was another driver of the craft brewing movement. The 1980's and 90's saw the emergence of the "educated class" or the white collar meritocracy. The first great bump of baby-boomers graduated college in the 1970s. Since then, the growth of information technology (and the shifting nature of jobs around that technology) as well as the shift away from manufacturing employment has meant the development a large number of the well educated and well compensated. Brooks (2000) has argued this has led to a certain style of consumption. The educated class rejects conspicuous consumption of luxuries (such as boats or furs) but embraces spending a great deal for necessities (albeit at a very high end) and a cultivated appreciation of (versions of) commonplace goods. Brooks describes the ethos as one focusing on the "authentic, natural, warm, rustic, simple, honest, organic, comfortable, craftsmanlike, unique, sensible, sincere" (Brooks, 2000, p. 83; Binkley, 2007). Thus, we have seen the emergence of firms like Starbucks, Republic of Tea, Viking, Whole Foods, and so on.

These purchasing patterns readily extend to beer, particularly with respect to local breweries as an alternative to the uniform products of mega-breweries. Early on, this manifested as a growth in import beer sales in the early 1980s. While this has persisted, the real growth has been in the conscious consumption of locally and regionally produced beers that emphasize either a resurrection of old styles of beer (such as ales, porters, stouts, lambics and the like) or particularly American interpretations of these styles such as American Pale and pumpkin ales, and rye and chile beer. As an illustration of this growth, the Beer Advocate website lists reviews of over 13,000 labels in the American Ale section (Beer Advocate, 2010). In addition, while beer is generally regarded as a bluecollar beverage and wine a more upscale and white collar drink, the craft brewing industry's approach to product development has tapped a demographic that overlaps with that of wine drinkers: craft brew consumers are young (wine drinkers tend to be older) but both are affluent, and well educated. In fact, many craft brew consumers are also wine drinkers, which is not true of more traditional beer consumers. This is why drinking craft beers is increasingly being positioned as a wine-like experience (Student, 1995; Adams, 2009; Hallinan, 2006).

In this context, then, the standard American lager may have been perceived as too mainstream, bland, or boring to fit well with the new consumption patterns. The arc of product development in American beer has always been toward lighter beers (lagers vs. ales in the 1840's, Bavarian vs Munich styles in the 1870s, the effect of prohibition on American tastes vis a vis bitterness, carbonation (the Coca Cola effect), the effect of increasingly national markets and subsequent product characteristics for single product solution, and changing economics of brewing). Over this period, brewers reduced the amount of malted barley in brew recipes from 36 pounds per barrel to 24 (which diminished the body of the beer), the total fermentables from 49 to 35 pounds (reducing alcohol content as well), and hops from 0.65 pounds to 0.22 (reducing the bitterness of the beer) (Choi and Stack, 2005). Another factor was the near universal penetration of refrigeration into homes. While refrigeration made packaging for home consumption possible (and profoundly changed industry distribution), it had another effect. Cold temperatures do not permit oils and esters in foods to become volatile so refrigerator-cold beer has very little flavor or aroma. Thus, what makes up a beer matters less and less as the dominant perceptions are of temperature and carbonation. Ultimately, these factors point toward a convergence of styles resulting in beers that are very uniform in terms of production and quality control but deficient in flavor and aroma compared to other styles of beer. This approach may have reached its nadir by 1984 when Falstaff introduced generic beer.

The confluence of these factors - changes in regulation, taste, and the experience in brewing - led to the dramatic growth in breweries in the U.S. in the 1990s. To be sure, this was not a smooth growth process. The industry has experienced an ongoing shakeout among small craft brewers for several reasons. First, many failed to make the production scale transition from kitchen to plant. Brewing 500 gallons of beer is a very different process 
than brewing five gallons. One of the results was that craft beer often wasn't that good. A 1996 Consumer Reports test indicated that many highly regarded craft beers were actually flawed, stale, or sour. Second, even if the early entrepreneurs knew how to make beer, they often weren't very effective business managers. According to one craft brew executive, the brewers who are succeeding "are the ones that have either made the transition themselves to learn how to be more savvy business people or created a partnership with someone who does" ("Craft Brewers", 2007).

\section{AUTHOR INFORMATION}

Dr. Alfred Warner is an Associate Professor of Management at Penn State Erie focusing on business strategy and international business issues. Research interests are in industry and firm level response to technological change and industry evolution.

\section{REFERENCES}

1. Adams, S. (2009, April 25). Craft beer sales on the rise. Patriot Ledger, 25 April. Retrieved Jan 2 from http://www.patriotledger.com/business/x1899319866/Craft-beer-sales-on-the-rise.

2. Associated Press (2007, Dec 13). Craft brewers reaching sobering conclusion. Retrieved Jan 5, 2010 from http://www.msnbc.msn.com/id/22245889.

3. Baron, S. (1962). George Washington: President and beer lover. Retrieved Jan 15, 2010, from

BeerHistory.com: http://www.beerhistory.com/library/holdings/washingtonbeerlover.shtml.

4. Beer Advocate. (2010). Beer styles. Retrieved June 4, 2010 from: http://beeradvocate.com/beer/style.

5. Beer History. (2007). Shakeout in the brewing industry. Retrieved Jan. 17, 2010 from:

http://www.beerhistory.com/library/holdings/shakeout.shtml.

6. $\quad$ Beer Institute. (2009) Brewers Almanac 2009. Retrieved Jan. 10, 2010 from:

http://www.beerinstitute.org/statistics.asp?bid=200 .

7. Beer Institute. (2010) The Pilgrims and Beer. Retrieved Jan. 25, 2010 from:

http://www.beerinstitute.org/tier.asp?bid=141.

8. Benson-Armer, R., Leibowitz, J., \& Ramachandran, D. (1999). Global Beer: What's on tap? The McKinsey Quarterly, 1999, 1, p. 111-121.

9. Berman, D, \& Frank, R. (2004, July 21). Coors and Molson close to saying they have a deal. Wall Street Journal, p. B3.

10. Binkley, S. (2007). Getting Loose: Lifestyle consumption in the 1970s. Durham, NC and London: Duke University Press.

11. Beer History. (1955). Brewing from malt to market. Retrieved Jan. 15, 2010 from: http://www.beerhistory.com/library/holdings/brewingprocess.shtml.

12. Brewers Association. (2009a). Craft Brewer Defined. Retrieved Jan. 3, 2010 from: http://www.brewersassociation.org/pages/business-tools/craft-brewing-statistics/craft-brewer-defined.

13. Brewers Association. (2009b). Market segments. Retrieved Jan. 3, 2010 from: http://www.brewersassociation.org/pages/business-tools/craft-brewing-statistics/market-segments.

14. Brooks, D. (2000). Bobos in paradise: The new upper class and how they got here. New York: Simon \& Schuster.

15. Carter, A. (2005, Jan. 14). SABMiller's taste for Molson. Business Week, p. 1.

16. Chipello, C. J. \& Frank, R. (2004, Sept. 24). A Canadian-American beer bash. Wall Street Journal, p. C1.

17. Chipello, C. J. \& Lawton, C. (2005, Jan. 31). Molson shareholders approve proposal to merge with Coors. Wall Street Journal, p. C4.

18. Choi, D. Y. \& Stack, M. H. (2005). The all-American beer: A case of inferior (taste) prevailing? Business Horizons, v. 48, p. 79-86.

19. Dalton, M. (2009, April 17). AB InBev suppliers feel squeeze: Smaller companies complain of brewing behemoth's newfound muscle. Wall Street Journal, p. B2.

20. Devaney, P. J. (1998, June 10). World Watch. Wall Street Journal, p. 1.

21. Dow-Jones Newswires (2003, May 2). Heineken NV: Deal to acquire brewer BBAG likely to be announced today. Wall Street Journal, 1.

22. Dow-Jones Newswires. (2004, Aug. 11). Heineken NV. Wall Street Journal, p.1. 
23. Dow-Jones Newswires. (2005, May 9). Russian brewer is acquired, lifting market share to $8.3 \%$. Wall Street Journal, p.A17.

24. du Bois, M. (1996, Nov. 26). Interbrew's toast: Here's to niche beers. Wall Street Journal, Eastern Edition, p. A16.

25. $\quad$ Economist (2008, June 14). Hands off our Bud. 387, 8584, p. 86.

26. Economist (2008, June 21). A bid for Bud. 387, 8585, p. 91.

27. Economist (2008, June 28) "Crying into their beer: Budweiser and St. Louis. 387, 8586.

28. Foust, D., Ewing, J., \& Smith, G. (2008, June 28). Looks like a beer brawl. Business Week, p. 52.

29. Frank, R., Lawton, C. \& Chipello, C.J. (2005, Jan. 11). Coors-Molson deal is going flat: As more holders cite risks of current merger pact, brewers may top up offer. Wall Street Journal, p. A3.

30. Germans in America. (2009). In European Reading Room, Library of Congress. Retrieved Jan. 15, 2010 from: http://www.loc.gov/rr/european/imde/germchro.html.

31. Gibson, R. (1993, Mar. 23). Anheuser-Busch to buy 18\% stake in Mexican brewer. Wall Street Journal, p. B4.

32. Grace, R. (2005). Anheuser Busch brings suit against 'DuBois Budweiser'. Retrieved Jan. 17, 2010 from http://www.metnews.com/articles/2005/reminiscing080405.htm.

33. Hallinan, J.T. (2006, Nov. 20). Craft beers have big breweries thinking small. Wall Street Journal, p. B1.

34. Hanson, D.J. (2009). Minimum legal drinking ages around the world. Retrieved Jan. 8, 2010 from http://www2.potsdam.edu/hansondj/LegalDrinkingAge.html .

35. Dow-Jones Newswires. (2004, Aug. 11). Heineken NV. Wall Street Journal, p.1.

36. Kesmodel, D. \& Ball, D, (2007, Oct. 10). Miller, Coors to shake up U.S. beer market. Wall Street Journal, p. A1.

37. Kesmodel, D. \& Kamitsching, M. (2008, June 12). InBev uncorks Anheuser-Busch takeover bid: BelgianBrazilian giant offers $\$ 46.4$ billion for U.S. icon. Wall Street Journal, Eastern Edition, p. A1.

38. Kesmodel, D., Kamitsching, M., \& Cimilluca (2008, July 14). Anheuser, InBev reach a deal for $\$ 52$ Billion. Wall Street Journal, 14 July, Eastern Edition, p. B1.

39. Kesmodel, D. \& Vranica, S. (2009, April 29). Unease brewing at Anheuser as new owners slash costs. Wall Street Journal, Eastern Edition, p. A1.

40. McGahan, A.N. (1991). The emergence of the national brewing oligopoly: Competition in the American market, 1933-1958. Business History Review, 65, 2, p. 229-284.

41. Mittelman, A. (2008). Brewing battles: A history of American Beer. New York: Algora Publishing.

42. Ogle, M. (2006). Ambitious brew: The story of American beer. Orlando, FL: Harcourt Books.

43. Palmer, J. (2006). How to brew. Boulder, CO: Brewers Publications.

44. Phillips, M. (2007, Oct. 9). Pouring it on. Wall Street Journal (online edition).

45. Raghavan, A \& Johnson, K. (1999, June 10). Heineken nears deal to acquire Spanish brewing unit of Diageo. Wall Street Journal, p.A18.

46. RealBeer. (2001). Coors buys Carling (2001). Retrieved Dec. 24, 2009 from: http://www.realbeer.com/news/articles/news-001638.php.

47. SAB Miller. (2009). Heritage. Retrieved Dec. 13, 2009 from SABMiller: http://www.sabmiller.com/index.asp?pageid=27.

48. Samor, G. \& Bilefsky, D. (2004, Mar. 3). Interbrew, AmBev reach merger accord. Wall Street Journal, p. A3.

49. Stack, M. (2000). Local and regional breweries in America's brewing industry, 1865-1920. The Business History Review, 74, 3, p. 435-463.

50. Steiner, S. (2000). The German revolution of 1848/49. Retrieved Jan. 15, 2010 from the http://www.germanheritage.com/Essays/1848/unity and_justice and freedom.html.

51. Student, J. (1995). True Brew. American Demographics, 17, 5, p. 32-39.

52. Vranica, S. \& Kang, S. (2008, June 13). InBev may water down Bud's marketing. Wall Street Journal, Eastern Edition, p. B6. 